\title{
Breeding Sites of Culex quinquefasciatus (Say) during the Rainy Season in Rural Lowland Rainforest, Rivers State, Nigeria
}

\author{
S. N. Okiwelu*, M. A. E. Noutcha \\ Entomology and Pest Management Unit, Department of Animal and Environmental Biology. University of Port Harcourt, Port Harcourt, \\ Nigeria
}

\begin{abstract}
Breeding sites of Culex quinquefasciatus (Say) were investigated during a World Bank Assisted Project on Integrated Vector Management (IVM) for malaria control at 5 villages (Ipo, Ozuaha, Omanwa, Omademe, Ubima) in the Ikwerre Local Government Area (LGA). The study was in the rainy season, June-September, 2009, in ru ral lowland ra inforest, Rivers State, Nigeria. Sampling was undertaken daily in a randomly selected (100 m x $100 \mathrm{~m})$ grid in each village. Number of $C x$. quinquefasciatus (Say) immatures was approximately 6-fold that of An. gambiae s.1. Nearly $80 \%$ of $C x$. quinquefasciatus immatures were from container-type breeding sites (metal, plastic containers, "calabashes", tyres) and least fro m phytotelmata. The differences were significant $\left(\mathrm{F}_{\mathrm{Cal}}=35695636 ; \mathrm{F}_{\mathrm{Tab}}=39.86 ; \mathrm{df} 1,1 ; \mathrm{p}<0.01\right)$. Plastic containers were the preferred site-type in this category. The container-type breeding sites also yielded the highest number of immatures per breeding site. In the pools breeding site-types, approximately 55\% were from puddles and $45 \%$ from gutters; the difference was not significant $\left(\mathrm{F}_{\mathrm{Cal}}=334975 ; \mathrm{F}_{\mathrm{Tab}}=39.86\right.$; df 1,$\left.1 ; \mathrm{p}>0.01\right)$. In the phytotelmata breeding site-types, about $67 \%$ of $C x$. quinquefasciatus immatures were from depressions on trees; the difference in total numbers among site-types was significant $\left(\mathrm{F}_{\mathrm{Cal}}=2.47 \times 10^{8} ; \mathrm{F}_{\mathrm{Tab}}=39.86 ;\right.$ df 1,$\left.1 ; \mathrm{p}<0.01\right)$. The container-type breeding sites yielded approximately $90 \%$ of immatures at Omanwa, but decreased to $60 \%$ at Omademe. In contrast, nearly $70 \%$ of immatures we re from pools at Ozuaha and $80 \%$ from phytotelmata at Ubima. These variat ions were significant $\left(\mathrm{F}_{\mathrm{Cal}}=4305.94 ; \mathrm{F}_{\mathrm{Tab}}=39.86 ; \mathrm{df} 1,1 ; \mathrm{p}<0.01\right)$. The results indicate that $C x$. quinquefasciatus had invaded rural areas and their breed ing sites ubiquitous and variable among villages, highlighting the needs for studies locally, prior to larviciding.
\end{abstract}

Keywords Culex Qu inquefasciatus, Breeding Sites, Containers, Pools, Phytotelmata, Rural Lowland Ra inforest, Nigeria

\section{Introduction}

It is estimated that globally, 1.2 billion people are at risk to ly mphatic filariasis (LF), major cause of acute and chronic morbidity affecting humans in tropical and subtropical countries[1,2]. The absence of a nonhuman reservoir, availability of safe, single-dose, two-drug treatment regimes, capable of reducing microfilariae to very low levels and remarkable improvement in techniques for diagnosing the disease, resulted in advocacy for a global strategy to eliminate filariasis through mass drug administration (MDA)[3]. This culminated in a global alliance by the World Health Organization and other agencies to eliminate lymphatic filariasis by 2020[4]. The main goal is to break the cycle of transmission of the parasites, between mosquitoes and humans mainly through MDA with Albendazole in combination with either Ivermect in or Diethylcarbamazine citrate[5]. Although there had been progress since the initiation of

* Corresponding author:

okiwelu2003@yahoo.com (S.N. Okiwelu)

Published online at http://journal.sapub.org/phr

Copyright (C) 2012 Scientific \& Academic Publishing. All Rights Reserved
MDA Programmes, challenges have emerged. These include: the inability of some countries to sustain MDA, non- availability of data to indicate level and duration of treatments to eliminate LF, and a shift towards linking MDA for LF control and other neglected diseas es[6]. These challenges have led to growing concerns on the effectiveness of MDA alone to eliminate LF, without vector control as a complement[7]. Thus an integrated strategy involving vector control is now thought to have great potential to become an important supplementary component of the filariasis elimination campaign.

Culex quinquefasciatus (Say) is an urban vector of nocturnally periodic Wuchereria bancrofti in West Africa[8]. The distribution of the urban vector of bancroftian filariasis, Cx. quinquefasciatus is expanding with urbanization; many rural areas that were free of this vector are now being colonized[9]. Reliable data on breeding sites of species ensure the effectiveness of new control methods. Nicolas et al.[10] controlled this species, by applying Bacillus sphaericus against the immatures at breeding sites; they estimated that this approach would be more cost effective than the use of chemical insecticides. There had been reports of cases of bancroftian filarias is in rural Local Government Areas (LGAs) adjacent to the Ikwerre LGA of Rivers State, Nige- 
ria $[11,12]$. Records indicate that patients had been treated for filariasis in the General hospital at Isiokpo, Ikwerre LGA headquarters. Studies were therefore undertaken, JuneSeptember, 2009 (Rainy season) in 5 villages (Ozuaha, Ipo, Omanwa, Omademe, Ubima) in Ikwerre LGA, Rivers State, Nigeria. These villages were selected by the State Government for a World Bank-assisted project on Integrated Vector Management (IVM) for malaria control. Studies on Cx. quinquefaciatus were undertaken simultaneously with those on Anopheles spp. to determine whether Cx. quinquefasciatus described as primarily urban (service 2008) had invaded rural areas and to identify their breed ing sites.

\section{Materials and Methods}

\subsection{Study Area}

The 5 villages IPO $\left(06^{\circ} 57.5^{\prime} \mathrm{N}, 05^{\circ} 02.3^{\prime} \mathrm{E}\right)$, OMANWA $\left(06^{\circ} 53.5^{\prime} \mathrm{N}, 05^{\circ} 03.8^{\prime} \mathrm{E}\right)$, OZUAHA $\left(06^{\circ} 55.3^{\prime} \mathrm{N}, 05^{\circ} 03.5^{\prime} \mathrm{E}\right)$, OMADEME $\left(06^{\circ} 57.5^{\prime} \mathrm{N}, \quad 05^{\circ} 05.1^{\prime} \mathrm{E}\right)$ and UBIMA $\left(06^{\circ} 54.2^{\prime} \mathrm{N}, 05^{\circ} 07.4^{\prime} \mathrm{E}\right)$ are located in the lowland rainforest. Ubima and Ozuaha were more developed (paved roads and modern housing) while Ipo and Omanwa were the most rural. There are 2 seasons April-September (rainy) and October-March (dry). The main occupation of the local people is farming; some are involved in wildlife hunting and bush meat trade.

\subsection{Methods}

A $100 \times 100 \mathrm{~m}$ grid was randomly selected in each village. Potential breeding sites were sampled with a $100 \mathrm{ml}$-laddle and a Pasteur pipette for sites with large and small volumes of water respectively, daily for 4 months, June-September, 2009. These sites included Phytotelmata (water-containing holes in plants), Pools (puddles, gutters) and containers (water receptacles in villages, such as the calabash, from the fruit of Cresenta cujeta Linn, Bignonaceae), plastic and metallic containers. Culex larvae were identified by the descriptions in Service[13]. Immatures were reared to adults to confirm that they were those of $C x$. quinquefasciatus as per the keys of Gilles and de Meillon[14] and Gillett[15]. Anopheles gambiae s.l. immatures were also collected and reared to adults during the study. Adults of An.gambiae s.1. were identified by the keys of Holstein[16], Gillett[15] and Louis[17]. Numbers of immatures were recorded as per breeding site-types and villages. Analys is of Variance with one observation per cell was used for statistical analyses. Calculated $\mathrm{F}$ values were compared to tabulated $\mathrm{F}$ values to determine significance.

\section{Results}

\subsection{Diversity and Yield of Breeding Site-Types}

The total number of $C x$. quinquefasciatus immatures was approximately 6-fold that of An. gambiae s.l. immatures.
Nearly $80 \%$ of all immatures were collected from container-type breeding sites (metal and plastic containers, "calabash", and tyres) and least (about 5\%) from phytotelmata (Table1). The differences were significant $\left(\mathrm{F}_{\mathrm{Cal}}=35695636 ; \mathrm{F}_{\mathrm{Tab}}=39.86 ;\right.$ df 1,$\left.1 ; \mathrm{p}<0.01\right)$. The highest number of immatures per breeding site was also in the container category (Table 2); the differences were significant $\left(\mathrm{F}_{\mathrm{Cal}}=16.5\right.$; df 1,$\left.3 ; \mathrm{p}<0.05\right)$. Approximately $80 \%$ were from plastic containers and least $1 \%$ from tyres in the container-type breeding sites. The differences were significant $\left(\mathrm{F}_{\mathrm{Cal}}=4.7 \times 10.8 ; \mathrm{F}_{\mathrm{Tab}}=8.53\right.$; df 1,$\left.2 ; \mathrm{p}<0.01\right)$. The highest number of immatures per breeding site was fro m calabash in the container-type (Table 3 ); the differences were significant $\left(\mathrm{F}_{\mathrm{Cal}}=23.1 ; \mathrm{df1}, 2 ; \mathrm{p}<0.05\right)$. In the pools breeding site- type, approximately $55 \%$ of immatures were from puddles and the rest from gutters; the difference was not significant $\left(F_{\mathrm{Cal}}=334975 ; \mathrm{F}_{\mathrm{Tab}}=39.86\right.$; df 1,$\left.1 ; \mathrm{p}>0.01\right)$, but the difference in the number per breed ing site between puddles and gutters was significant $(\mathrm{F}=18.16$; df 1,$3 ; \mathrm{p}<0.05)$. Percent occurrence of $C x$. quinquefasciatus immatures varied among breeding site categories: containers (69.23-100.00\%), Pools (66.67-76.47\%) and phytotelmata (75.0-82.93\%) (Table4). In the phytotelmata breeding site-type, about $67 \%$ of immatures were collected from depressions on trees; the difference in total numbers among site-types was significant $\left(\mathrm{F}_{\mathrm{Cal}}=2.47 \times 10^{8} ; \mathrm{F}_{\mathrm{Tab}}=8.53 ; \mathrm{df} 1,1 ; \mathrm{p}<0.01\right)$.

\subsection{Variation in Site-Type Utilization across Villages}

At Ipo and Omanwa, about $90 \%$ of immatures were from container-type breeding sites; this figure decreased to $60 \%$ at Omademe. In contrast, at Ozuaha, nearly $70 \%$ of immatures were from pools, while at Ubima more than $80 \%$ were from phytotelmata. The variations in breeding site preference patterns among villages were significant $\left(\mathrm{F}_{\mathrm{Cal}}=4305.94\right.$; $\mathrm{F}_{\mathrm{Tab}}=39.86$; df 1,$\left.1 ; \mathrm{p}<0.01\right)$.

Table I. Numbers of Immature Culex quinquefasciatus from various breeding site-types

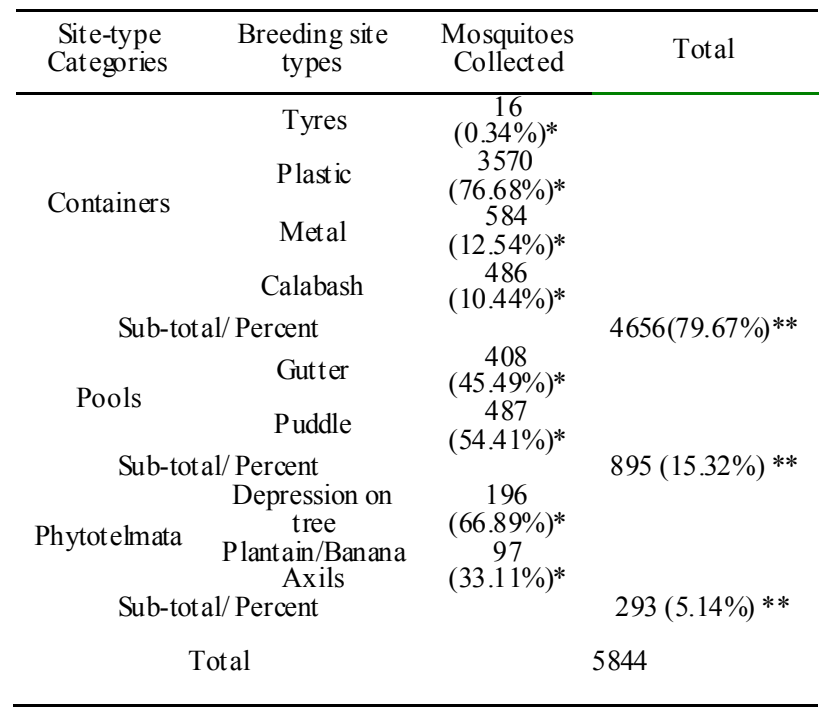

(*) Percent of total in each site-type category

(**) Percent in each site-type category of total collected during study 
Table 2. Numbers of Culex quinquefasciatus Immat ures at Different Breeding Sites in the Five Villages

\begin{tabular}{|c|c|c|c|c|c|c|c|c|c|}
\hline \multirow{3}{*}{ Villages } & \multicolumn{8}{|c|}{ Breeding Sites } & \multirow{3}{*}{ Total } \\
\hline & \multicolumn{4}{|c|}{ Containers } & \multicolumn{2}{|c|}{ Pools } & \multicolumn{2}{|c|}{ Phytotelmata } & \\
\hline & Plastic & Metal & Calabash & Tyre & Gutter & Puddle & Depression on tree & Plantain/ Banana Axils & \\
\hline Ozuaha & $87(18.67)^{*}$ & $37(7.94)$ & $0(0.00)$ & $3(0.64)$ & $307(65.88)$ & $5(1.07)$ & $0(0.00)$ & $27(5.79)$ & 446 \\
\hline Ipo & $2300(84.17)$ & $49(1.79)$ & $337(12.33)$ & $0(0.00)$ & $0(0.00)$ & $0(0.00)$ & $0(0.00)$ & $47(1.72)$ & 2733 \\
\hline Omanwa & $539(52.38)$ & $289(28.09)$ & $119(11.57)$ & $7(0.68)$ & $71(6.90)$ & $1(0.10)$ & $0(0.00)$ & $3(0.29)$ & 1029 \\
\hline Omademe & $644(45.71)$ & $191(13.56)$ & $30(2.13)$ & $6(0.43)$ & $13(0.93)$ & $481(34.14)$ & $44(3.12)$ & $0(0.00)$ & 1409 \\
\hline Ubima & $0(0.00)$ & $18(8.70)$ & $0(0.00)$ & $0(0.00)$ & $17(8.21)$ & $0(0.00)$ & $152(73.43)$ & $20(9.66)$ & 207 \\
\hline Total & 3570 & 584 & 486 & 16 & 408 & 487 & 196 & 97 & 5844 \\
\hline
\end{tabular}

() Percent of total immatures in each village

Table 3. Numbers of Culex quinquefasciatus per Breeding Site

\begin{tabular}{|c|c|c|c|c|}
\hline $\begin{array}{c}\text { Site-Type Catego- } \\
\text { ries } \\
\end{array}$ & Breeding Site- types & $\begin{array}{c}\text { Number of Breeding Site } \\
\text { Examined }\end{array}$ & $\begin{array}{c}\text { Number of Immat ures Col- } \\
\text { lected }\end{array}$ & $\begin{array}{c}\text { Number per Breeding } \\
\text { Site } \\
\end{array}$ \\
\hline \multirow{4}{*}{ Containers } & Tyres & 9 & 16 & 1.78 \\
\hline & Plastic & 43 & 3570 & 83.02 \\
\hline & Metal & 12 & 584 & 48.67 \\
\hline & Calabash & 2 & 486 & 243.00 \\
\hline \multicolumn{2}{|r|}{ Sub-total } & 66 & 4656 & 70.55 \\
\hline \multirow{2}{*}{ Pools } & Gutter & 24 & 408 & 17.00 \\
\hline & Puddle & 13 & 487 & 37.46 \\
\hline \multirow{5}{*}{ Phytotelmata } & Sub-total & 37 & 895 & 24.19 \\
\hline & Depression on tree & 6 & 196 & 32.67 \\
\hline & Plantain/ Banana Axils & 34 & 97 & 2.85 \\
\hline & Sub-total & 41 & 293 & 7.33 \\
\hline & Total & 144 & 5844 & \\
\hline
\end{tabular}

Table 4. Percent Occurrence of Culex quinquefasciatus at Breeding Site-types

\begin{tabular}{|c|c|c|c|c|}
\hline Site-Type Categories & Breeding Sites & $\begin{array}{l}\text { Number of Breeding } \\
\text { Sites Examined }\end{array}$ & $\begin{array}{c}\text { Number of Breeding Sites Yielding } \\
\text { Immatures }\end{array}$ & $\begin{array}{c}\text { Percent of Immature } \\
\text { Occurrence }\end{array}$ \\
\hline \multirow{4}{*}{ CONT AINERS } & Tyres & 13 & 9 & 69.23 \\
\hline & Plastic & 45 & 43 & 95.56 \\
\hline & Metal & 12 & 12 & 100.00 \\
\hline & Calabash & 2 & 2 & 100.00 \\
\hline \multirow{4}{*}{ POOLS } & & & $91.45^{*}$ & \\
\hline & Gutter & 36 & 24 & 66.67 \\
\hline & Puddle & 17 & 13 & 76.47 \\
\hline & & & $71.57^{*}$ & \\
\hline \multirow{3}{*}{ PHYT OTELMAT A } & Depression on tree & 8 & 6 & 75.00 \\
\hline & Plantain / Banana Axils & 41 & 34 & 82.93 \\
\hline & & & $78.92 *$ & \\
\hline
\end{tabular}

Average \% occurren ce per site-type category

\section{Discussion}

The high numbers of total $C x$. quinquefasciatus larvae collected in the villages, indicated that the species, once considered an urban species[18, 13] is increasing in distribution and colonizing rural pockets that were once free of this mosquito, an aspect of $C x$. quinquefasciatus distribution that was also observed by Chavasse et al.[9]. In urban areas, the typical breeding sites were described as stagnant polluted water and in rural areas, mainly privies (pit latrines)[18, 13]. The extensive distribution of breeding sites (tyres, plastic and metal containers, calabashes, gutters, puddles, leaf axils, depressions on trees, etc) is an indication of changes in the oviposition behaviour of CX. quinquefasciatus; pit latrines, typical of polluted habitats did not occur in the randomly selected grids. The dominance of containers as breeding sites of $C x$. quinquefasciatus had been reported by Hardine et al.[19] and Bockarie et al.[8].
Potential capacity to enhance offspring survivorship and fecundity contributes by definition, to parental care or juvenile dispersal; offspring survival and growth may depend strongly on the quality of the habitat in which they are deposited. Thus, when potential habitats vary in their suitability for juveniles, females are expected to choose habitats that maximize fitness[20]. In mosquitoes, such oviposition habitat selection was demonstrated in response to physical and chemical suitability for larval development[21]. This may account for the variation in preference among metallic, plastic containers and, calabashes. The low numbers of immatures in phytotelmata site-types may be associated with habitat size and limited resource availability[22-24] .

Although container-type sites were preferred at Omanwa, Ipo and Omademe, pools and phytotelmata were the selected sites at Ozuaha and Ubima respectively. The pronounced preference for containers at Ipo and Omanwa might be attributed to the extreme rural conditions in the villages, lim- 
ited access to running water and therefore utilization of containers for collecting and storing rainwater. Unfortunately, these containers served as mosquito breeding sites. The dominance of phytotelmata at Ubima might be attributed to the extensive occurrence of plantain/banana groves in the randomly selected grids. These observations indicate that variations are common and therefore breeding site preference studies should be undertaken in each locality before the commencement of larviciding. The ubiquitous nature of $C x$. quinquefasciatus breeding sites is highlighted by its high percent occurrence in all site-type categories.

\section{Conclusions}

$C x$. quinquefasciatus, long considered an urban species has invaded the rural lowland rainforest. Most immatures were collected from container-type breeding sites (metal and plastic containers, "calabash", and tyres) and least from phytotelmata. The highest numbers of immatures were collected from plastic containers and calabashes. Degree of breeding-site utilization varied across villages.

\section{ACKNOWLEDGEMENTS}

This study was undertaken during a World Bank-funded project on the Indoor Residual Spray (IRS) - Integrated vector Management (IVM) for malaria control. The beneficiary was the Rivers State Ministry of Health, Port Harcourt, Nigeria. We are indebted to village chiefs, who granted us access to the study sites and the youths that served as guides in each of the villages. The commitment of Messrs Pasiya Otufu, Stephen Ozule and Ibrah im Sow Kamara during field work is appreciated. The assistance on statistical analyses by Mr Bukola A moo Oyebade of the Forestry Biometrics and Measurement Unit, Department of Forestry and Wildlife Management, Faculty of Agriculture, University of Port Harcourt is gratefully acknowledged.

\section{REFERENCES}

[1] Michael E., Bundy D.A., Grenfell B.T. 1996. Reassessing the global prevalence and distribution of lymphatic filariasis. Parasitology 112: 409-428.

[2] Michael E., Bundy D.A.P. 1997. Global mapping of lymphatic filariasis. Parasitol. Today 11:472-476.

[3] Molyneux D.H., Zagaria N. 2002. Lymphatic filariasis elimination: Progress in global program development. Ann. Trop. Med. Parasitol. (Suppl. 2) S 15-40.

[4] Yarney G. 2000. Global Alliance launches plan to eliminate lymphatic filariasis. Br. Med. J. 320:269.

[5] Ottesen E.A. 2000. The Global Programme to Eliminate Lymphatic Filariasis. Trop. Med. Int. Health. 5:591-594.
[6] Hotez P., Raff S., Fenwick A., Richards F. Jr., Molyneux D.H. 2007. Recent progress in integrated neglected tropical disease control. Trends in Parasitology 23: 511-514.

[7] Burkor T.R., Durrheim D.N., Melrose W.D. Speare R., Ichimori K. 2006. The argument for integrating vector control with multiple drug administration campaigns to ensure elimination of lymphatic filariasis. Filaria J. 5:1-7.

[8] Bockarie M.J., Pedersen E.M., White G.B., Michael E. 2009. Role of vector control in the Global Programme to Eliminate Lymphatic Filariasis. Annual Review Entomology. 54:469-487.

[9] Chavasse D.C., Lines J.D., Ichimori K., Marijani J. 1995. Mosquito control in Dar Es Salaam. I - Assessment of Culex quinquefasciatus breeding sites prior to intervention. Med. Vet. Entomol. 9:141-146.

[10] Nicolas L. Dossou-Yovo J., Hougard J-M. 1987. Persistence and recycling of Bacillus spaericus 2362 spores in Culex quinquefasciatus breeding sites in West Africa. Applied Microbiol. Biotech. 25:341-345.

[11] Amadi, E. C. 2000. Epidemiology and Entonological Studies of Filariasis in Ogoniland, Rivers State, Nigeria. PhD Dissertation, Department of Animal and Environmental Biology, University of Port Harcourt, Nigeria.

[12] Nwibari B.M.W. 2008. Studies on Malaria and Lymphatic Filariasis in Parts of Rivers State Nigeria. PhD Dissertation, Department of Animal and Environmental Biology, University of Port Harcourt, Nigeria.

[13] Service M. 2008. Medical Entomology for Students. $4^{\text {th }}$ edition. 289pp. Cambridge University Press.

[14] Gillies M.T., De Meillon B. 1968. The Anophelinae of Africa South of the Sahara Publication of the South African Institute for Medical Research, Johann esburg: 54.

[15] Gillett J.D. 1972. Common African Mosquitoes and their Medical Importance. 106pp. William Heinemann. Medical Books. London.

[16] Holstein M. 1960. Guide Pratique de l'Anophèle en Afrique Occidentale Francaise. Direction Générale de la Santé Publique. Service d'Hygiène Mobile et de Prophylaxie. Office de la Rech erche Scientifique d'Outre-Mer (ORSTOM), Dakar, P55.

[17] Louis F. 2003. Une clé d'identification des Anophèles. L'Aile. http://asmt.louis.free.fr/

[18] Mullen G.R. and Durden L.A. (Eds) 2009. Medical and Veterinary Entomology. $2^{\text {nd }}$ Edition. 637pp. Elsevier Academic Press.

[19] Hardine J.S., Brown C., Jones F., Taylor R. 2007. Distribution and habitats of mosquito larvae in the Kingdom of Tonga. Australian J. Entomol. 46:332-338.

[20] Kiflawi M., Blaustein L., Mangel M. 2003. Predation-dependent oviposition habitat selection by the mosquito Culiseta longiareolata: a test of competing hypotheses. Ecol. Lett. 6:35-40.

[21] Trimble R.M. 1979. Laboratory observations on oviposition by the predaceous tree hole mosquito, Toxorhynchtes rutilis septentrionalis. Canadian J. Zool. 57:1104-1108. 
[22] Blaustein I., Kotler B.P. 1993. Oviposition habitat selection by the mosquito, Culiseta longiareolata: Effects of conspecifics, food and green tadpoles. Ecol. Entomol. 18:104-108.

[23] Heard S.B. 1994a. Processing chain ecology: resource condition and interspecific interactions. J. Anim. Ecol. 63:451-464.
[24] Heard S.B. 1994b. Imperfect oviposition decision by the pitcher plant mosquito Wyeomyia- smithii. Evolutionary Ecology 8:493-502. 